\title{
IDÉIAS
}

\section{A cruzada da desburocratização no Brasil do cruzado}

\section{Celio frança (*)}

\section{I) A continuidade de uma Idéia}

1 oucas idéias, neste País, terāo sido tāo rápida e unanimemente assimiladas pela sociedade quanto a Desburocratizaçāo. Desde sua criaçāo, em 1979, o Programa tornou-se uma rejvindicaçāo popular. A opiniāo pública tomou como sua a injciativa de criaçāo tem participado ativamente do processo e reconhecido no Programa um canal importante de acesso e de intervençāo junto ao próprio Governo. Aproximou o Governo do Povo.

De outro lado, o Programa sempre foi organizado e operado de maneira ágil, leve e flexívcl. Credenciou-se, assim, perante à sociedade, pela velocidade, objetividade e relevância de suas iniciativas e, sobretudo, pela ausência de estrucuras burocráticas tradicionais. Um pequeno grupo de servidores que integrou a equipe do exMinistro Hélío Beltrāo encontraria terreno férti] para participar, pais afora, de extraordinário debate cívico, voltado sobretudo para a redução das formas de autoritarismo e discriminação social, politica e econômica embutidas em nossas arcaicas estruturas organizacionais.
Do mesmo modo, restaurou-se ou recriouse no Pais a dignidade do cidadāo diante do Governo e do Estado. A sociedade brasileira encontra-se em melhores condiçôes de exigir que - Serviço Público seja operado essencialmente como Serviço go Público, ao Cidadão e à própria Sociedade

A partir de 1985, o Ministro paulo Lustosa colocou o Programa a serviço das causas da cidadania e da defesa do consumidor. Características peculiares de ajustamento da própria equipe governamental e a exiguidade de tempo podem ter eventualmente contribuido para que se tenha a sensaçāo de que o Programa perderá um pouco da iniciativa e da velocidade de atuaçāo, característicos de sua fase inicial.

\section{2) A renrganização recente}

A reorganização do Programa $\mathrm{Na}$ cional de Desburocratizaçāo (PrND) cstá incluida entre as medidas de ajustamento do Governo Federal, adotados pelo Presidente José Sarncy no bojo da Reforma Ministerial. Extin-

1* Célıo França é Secretário-Execulivo do Programa Nacional de Desburocratızaça e presıdente da Câmara $V$ da Retorma Admınıstralıva Carıca, formado em Direıto e Admınıstraçăo, lez mestrado em Economia para o Desenvolvimenlo na Unıversidade de Pılısburg, e doutorado em Admınıslraçäo na Unıversıdade da Calılórnia.

guiu-se a figura do Ministro Extraordinário para Assuntos da Desburo cratização e transferiu-se para o âmbito do Minist ro da Administraçāo a competência de gestāo do Programa Nacional de Desburocratização, mantido, todavia, como Programa Especial de Governo.

A reorganização do PrND nestes termos restaura um modelo de organização já experimentado corn bastante sucesso no período em que o Ministro Hélio Beltrāo ocupou o Mjnistério da Previdência e Assistência Social, e Piquet Carneiro a Secretaría Executiva do PrND. A orientaçāo e coordenaçāo política do PrND em nível de Ministro de Estado asseguram as condiçōes necessárias à realização das tarefas a cargo do PrND.

\section{3) Os caminhos a seguir:}

Restaurar a vocaçāo do Programa a serviço do Cidadāo e a serviço da implementaçāo dos projetos prioritários, noladamente na área social. Como órgão de governo, o Programa tem como missão principal identificar os absurdos do sistema administrativo e tentar articular, junto aos diversos órgāos responsáveis pela função especifica, as soluçōes de Desburocratizaçāo, descomplicando a vida das pessoas, reduzindo excesso de interfcrência indevida do governo e melhorando o acesso à oferta dos serviços públicos essenciais.

A estratégia para viabilizar a implementação dessas idéias contém dois elmentos fundamentais: Primej- 


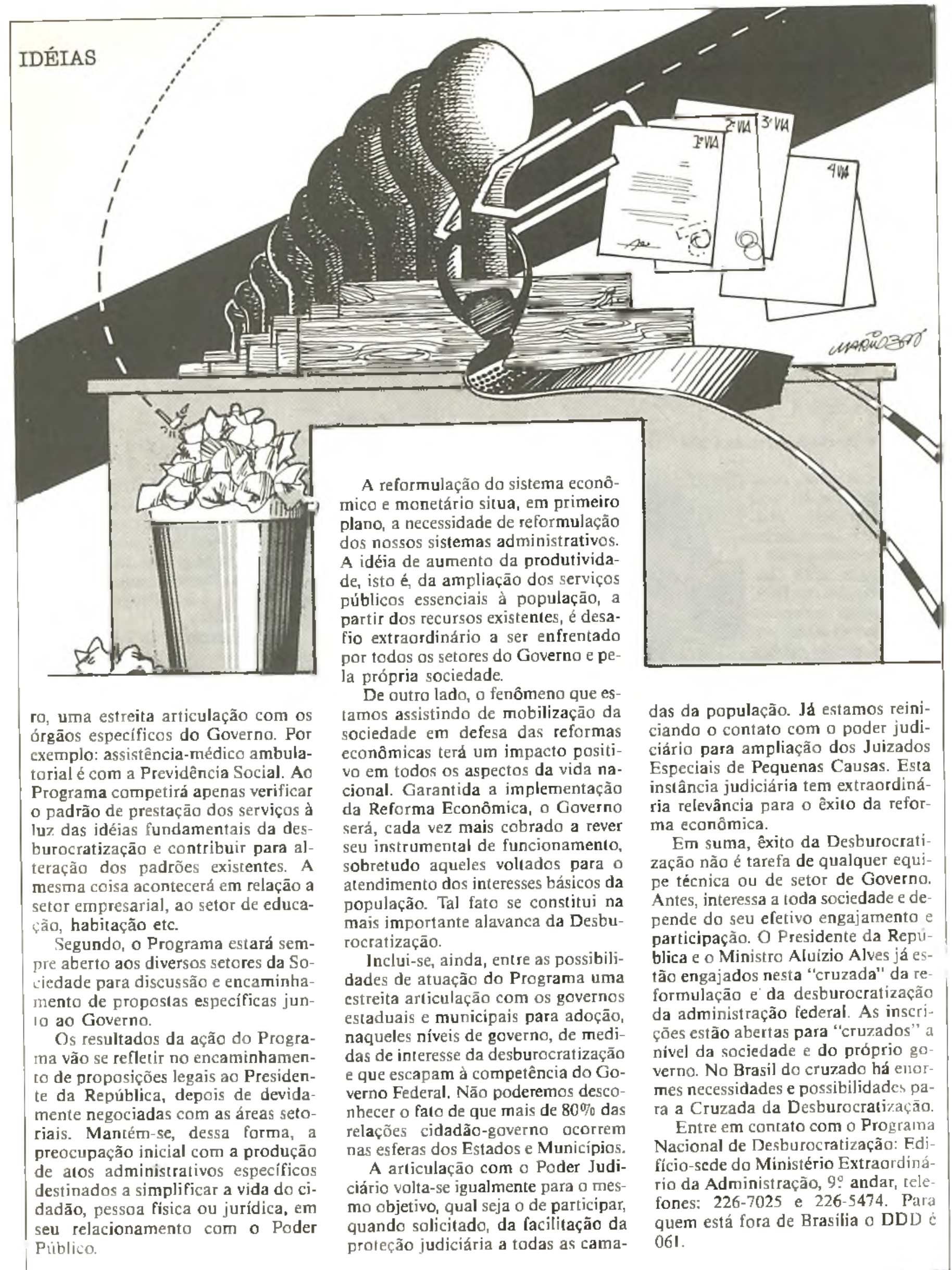

